\title{
Nutritional and environmental factors affecting plasma ghrelin and leptin levels in rats
}

\author{
Keiko Nakahara, Rieko Okame, Tetsuro Katayama' ${ }^{1}$, Mikiya Miyazato ${ }^{2}$, Kenji Kangawa² \\ and Noboru Murakami \\ Department of Veterinary Physiology, Faculty of Agriculture, University of Miyazaki, Miyazaki 889-2155, Japan \\ ${ }^{1}$ Genetic Resource Division, Frontier Science Research Center, University of Miyazaki, Miyazaki 889-2155, Japan \\ ${ }^{2}$ National Cardiovascular Center Research Institute, Osaka 565-8565, Japan \\ (Correspondence should be addressed to N Murakami; Email: a0d201u@cc.miyazaki-u.ac.jp)
}

\begin{abstract}
We examined which factors suppress the rise of ghrelin secretion under hunger in 16-h-starved rats, and compared the responses of plasma ghrelin and leptin levels to various exogenous and endogenous stimuli in intact rats. Although an acute expansion of the stomach by infusion of $6 \mathrm{ml}$ air or $3 \mathrm{ml}$ water in rats starved for $16 \mathrm{~h}$ did not change the level of plasma acyl-ghrelin $3 \mathrm{ml}$ corn starch solution, corn oil, or $20 \%$ ethanol significantly decreased it. Vagotomy inhibited suppression by nutrients but not by ethanol. Chronic infusion of ethanol into the stomach for 3 weeks in free-feeding rats caused widespread injury of the stomach mucosa, and increased both plasma ghrelin levels and the number of ghrelin cells. In intact rats, low temperature did not change ghrelin levels, but increased leptin levels. On the other hand,
\end{abstract}

restriction stress decreased plasma ghrelin levels, but had the reverse effect on plasma leptin levels. Although insulin decreased and 20\% glucose increased plasma glucose levels, they both decreased plasma ghrelin levels. Insulin elevated plasma leptin levels, but glucose had no effect. These results indicate that 1) acyl-ghrelin secretion from the stomach under fasting condition is suppressed by nutrients but not by mechanical expansion of the stomach; 2) high and low environmental temperature, stress, or administration of insulin reciprocally affect plasma levels of ghrelin and leptin; and 3) an increase of stomach ghrelin cell number and plasma ghrelin levels after chronic ethanol treatment may be involved in restoration of gastric mucosae.

Journal of Endocrinology (2010) 207, 95-103

\section{Introduction}

The peptide ghrelin consisting of 28 amino acids including an $O-n$-octanoylated Ser 3 residue has been identified as an endogenous ligand for the GH secretagogue receptor (GHSR; Kojima et al. 1999). This $O-n$-octanoylated Ser 3 residue is essential for ligand-receptor interaction. GHSR 1a is the only receptor specific for acylated ghrelin that has been identified so far (Kojima \& Kangawa 2005). Although ghrelin is synthesized in many tissues, including stomach, pancreas, cardiovascular tissue, hypothalamus, pituitary, kidney, and placenta (Mori et al. 2000, Gualillo et al. 2001, Hattori et al. 2001, Korbonits et al. 2001, Date et al. 2002b), the main source of plasma ghrelin is X/A-like cells localized in the oxyntic gland in the mucosa of the gastric fundus (Date et al. 2000, Hosoda et al. 2000). In addition to its GH-stimulating action, many physiological functions of ghrelin have been revealed during the last decade, including the regulation of food intake, energy metabolism, gastrointestinal coordination, cell proliferation, apoptosis, cardiovascular function, and secretion of insulin and gut hormones (Nakazato et al. 2001, Kojima \& Kangawa 2005, Nakahara et al. 2006, Zhang et al. 2008).
On the other hand, the peptide leptin consisting of 167 amino acids has been identified as a contributor to obesity in ob/ob mice (Zhang et al. 1994, Pelleymounter et al. 1995). Leptin is synthesized and released in the systemic fat tissues (white adipose tissue) or the placenta (Pelleymounter et al. 1995, Masuzaki et al. 1997, Friedman \& Halaas 1998), and plays an important role in the regulation of food intake, energy consumption, glucose metabolism, the cardiovascular system, the immune system, and the secretion of insulin and pituitary hormone (Friedman \& Halaas 1998, Ahima \& Flier 2000).

Although ghrelin and leptin have many functions in common, most of their functions conflict. Ghrelin generally increases body mass by increasing food intake and decreasing energy consumption, while leptin decreases body mass by decreasing food intake and increasing energy consumption (Friedman \& Halaas 1998, Kojima \& Kangawa 2005). These results suggest that ghrelin and leptin play important roles in maintaining energy balance and the homeostasis of body mass.

Among many studies of physiological functions of gherlin and leptin, their relation to obesity, and their molecular mechanisms, few studies have reported which exogenous or endogenous factors influence their secretion. Ghrelin secretion 
in the stomach is promoted by hunger and suppressed by food intake (Kojima \& Kangawa 2005). Although the effects of oral treatment with macronutrients on the plasma ghrelin levels in fasting rats were investigated, only total ghrelin levels were measured, but not acyl-ghrelin levels (Beck et al. 2002, Greenman et al. 2004, Heath et al. 2004, Bowen et al. 2006). Total ghrelin levels may correlate with acyl-ghrelin levels, yet long-term fasting inhibits ghrelin acylation without changing total ghrelin levels (Nass et al. 2008). Treatment with gut hormone (such as gastrin or cholecystokinin) and pancreatic hormone (such as glucagon, insulin, or somatostatin) also affects ghrelin secretion (Toshinai et al. 2001, Shimada et al. 2003, Kojima \& Kangawa 2005, Katayama et al. 2007). On the other hand, leptin secretion is increased by sympathetic nerve stimulation, food intake, glucocorticoid, tumor necrosis factor- $\alpha$, interleukin- 1 , and insulin, and is decreased by starvation (Haynes et al. 1997, Trayhurn et al. 1999, Olszanecka-Glinianowicz et al. 2005, Szkudelski 2007).

Here, we examined which mechanical or nutritional stimuli directly suppressed acyl-ghrelin secretion in the stomach under hunger, and whether the vagus nerve is necessary for its suppression, using both intact and vagotomized rats with implanted gastric cannulae. We also examined the acute and chronic influences of alcohol on ghrelin secretion, since alcohol intake injures the stomach. Next, we investigated how exposure to high and low temperatures affected the plasma ghrelin and leptin levels. To separate the effects of temperature from the effects of stress, we stressed control rats by restricting their activity. Finally, we compared the effects of insulin and blood glucose levels on plasma ghrelin and leptin levels.

\section{Materials and Methods}

\section{Animals}

Six-week-old adult male Wistar rats were purchased from Charles River Japan Inc. (Shiga, Japan) and maintained under a $12 \mathrm{~h}$ light:12 h darkness light regimen (light on at $0700 \mathrm{~h}$ ) at $23 \pm 1{ }^{\circ} \mathrm{C}$. Animals were supplied with standard laboratory chow and water made available ad libitum. Each rat was handled for 5-10 min every day and was habituated to blood sampling by an incision to the tail tip until the initiation of experiments. All procedures were performed in accordance with the Japanese Physiological Society's guidelines for animal care.

\section{Experiments}

Experiment 1 Five 9-week-old rats were used in two replications of this experiment, 1 week apart. The rats were fitted with a stomach cannula 2 weeks before the experiment: a silicon tube (inside diameter: $1.0 \mathrm{~mm}$ and outside diameter: $1.5 \mathrm{~mm}$ ) was inserted into the cardiac part of the stomach and brought out through the dorsal neck. Before each experiment, the rats were starved for $16 \mathrm{~h}$ (1700-0900 h).
To examine which factors suppress or stimulate ghrelin secretion under hunger, we directly infused $6 \mathrm{ml}$ of air or $3 \mathrm{ml}$ of water, $3 \mathrm{ml}$ of $30 \%$ corn starch $(3.18 \mathrm{kcal} / \mathrm{rat}$; Wako Pure Chemical Industries, Ltd, Osaka, Japan) (to represent carbohydrate), $3 \mathrm{ml}$ of corn oil $(27.64 \mathrm{kcal} / \mathrm{rat}$; Nakarai Tesque Inc., Tokyo, Japan) (to represent fat), or $3 \mathrm{ml}$ of $20 \%$ ethanol (v/v $5.42 \mathrm{kcal} / \mathrm{rat})$ into the stomach at $0900 \mathrm{~h}$ through the cannula. We selected $6 \mathrm{ml}$ air in a preliminary experiment. Although $20 \%$ ethanol (about $1.14 \mathrm{~g} / \mathrm{kg}$ body weight) may be a low dose in rodent alcohol research, we selected it because direct infusion of a higher dose of ethanol into the empty stomach may have induced gastric pain or alcohol intoxication, and thus complicated our interpretation of the change in ghrelin levels after ethanol treatment. Blood samples $(60 \mu \mathrm{l})$ were collected through a tail tip incision at 20 , 60 , and $120 \mathrm{~min}$ after infusion from the conscious rats. We also examined the effects of corn starch, corn oil, and ethanol on the plasma ghrelin levels in starved rats in which bilateral subdiaphragmatic vagotomy had been performed 4 days earlier. The dosages of corn starch, corn oil, and ethanol administered to intact and vagotomized rats were the same.

In addition, the levels of ghrelin mRNA in the stomach were quantified in 16-h-fasted rats treated with water or $20 \%$ ethanol using real-time reverse transcription (RT)-PCR, as described previously (Sato et al. 2007). The rats were killed by decapitation $2 \mathrm{~h}$ after infusion of water or $20 \%$ ethanol into the stomach, and then the stomach was harvested. Total RNA was extracted from each stomach sample using an RNeasy Micro kit (Qiagen) and synthesized into first-strand cDNA using a High Capacity cDNA RT kit (Applied Biosystems, Foster City, CA, USA). A single tissue sample was sufficient for measuring the level of mRNA. An aliquot of first-strand cDNA (equivalent to 40-100 ng tissue) was quantified on a 7300 Real-time PCR system (Applied Biosystems) using TaqMan Gene Expression Master Mix (Applied Biosystems) with primers to amplify $\beta$-actin and ghrelin specifically. For these two genes, probe/primer kits were purchased from Applied Biosystems (TaqMan Gene Expression Assay ID: Rn00667869_m1, GenBank NM_031144 for $\beta$-actin, and Assay ID: Rn01425835_m1, GenBank NM_021669 for ghrelin).

Experiment 2 Each of eight 9-week-old rats was used to examine the effect of long-term treatment with ethanol (or water as a control) on plasma ghrelin levels. All the rats were fitted with a stomach cannula, as detailed in Experiment 1, and subsequently infused with ethanol three times a day (at 0730,1300 , and $1830 \mathrm{~h}$ ) for 3 weeks.

The concentration of ethanol and schedule of treatment were based on a method for inducing fatty liver (Nishimura et al. 2001). The dose of ethanol was gradually increased stepwise during 3 weeks. Blood samples were collected at $1300 \mathrm{~h}$ on 7, 14, and 21 days after initiation of treatment. Rats were killed on day 21, and each stomach was excised for immunohistochemical analysis of ghrelin. 
Experiment 3 To examine the influence of environmental low temperature or stress on ghrelin and leptin secretion, five 8 -week-old intact rats per group were used in this experiment. All the experiments were performed twice using new intact rats. For cold exposure, we transferred intact rats from their usual room $\left(23 \pm 1{ }^{\circ} \mathrm{C}\right)$ to cold room $\left(13 \pm 1{ }^{\circ} \mathrm{C}\right)$. The receiving cages were at the same temperature as the new room. As the rats had been fed ad libitum and were transferred at $0900 \mathrm{~h}$, it was likely that they were not hungry. As the rapid change of temperature could stress the rats in addition to the actual temperature treatment, we stressed some of the control rats by inserting them into a $23-\mathrm{cm}$ transparent plastic tube (internal diameter: $5.5 \mathrm{~cm}$ ) with a wire net flap without a change in the temperature. After the rats were transferred to their new housing, $60 \mu \mathrm{l}$ of blood were collected at 20,60 , and $120 \mathrm{~min}$.

Experiment 4 To compare the effects of insulin on the plasma levels of ghrelin and leptin, we injected intact rats s.c. with either $200 \mu \mathrm{l}$ of insulin (2 IU/kg body weight; Eli Lilly K.K. Japan) or $500 \mu \mathrm{l}$ of $20 \%$ glucose solution at $0900 \mathrm{~h}$. Five 8 -week-old intact rats per group were used in this experiment. All the experiments were performed twice using new intact rats. Blood $(100 \mu \mathrm{l})$ was collected at 0 (just before injection), 20, 60, and $120 \mathrm{~min}$ after treatment. Control rats were treated with saline solution.

\section{Immunohistochemical analyses for ghrelin}

The trimmed glandular part of the stomach was washed in saline and placed in $0 \cdot 34 \%$ formalin for 4 days at $4{ }^{\circ} \mathrm{C}$, and then transferred to $0 \cdot 1 \mathrm{M}$ phosphate buffer containing $20 \%$ sucrose. Sections were cut at $18 \mu \mathrm{m}$ on a cryostat at $-20{ }^{\circ} \mathrm{C}$. The sections were fixed for $20 \mathrm{~min}$ in $40 \%$ paraformaldehyde, blocked for $1 \mathrm{~h}$ in $5 \%$ normal donkey serum in PBST, and then incubated overnight at $4{ }^{\circ} \mathrm{C}$ with rabbit antiserum against rat ghrelin (Nakahara et al. 2006). After washing, they were incubated in a solution of Alexa-488-labeled anti-rabbit $\operatorname{IgG}$ antibody for $30 \mathrm{~min}$. Samples were observed under fluorescence microscope (Axioskop 2 Plus, Carl Zeiss GmbH, Jena, Germany). Digital images were adjusted for contrast and color in Adobe Photoshop CS4.

\section{Measurement of plasma acyl-ghrelin, leptin, and glucose}

Blood samples were collected into microtubes containing $500 \mathrm{~K} \mathrm{IU} / \mathrm{ml}$ aprotinin and $2 \mathrm{mg} / \mathrm{ml}$ EDTA-2Na, and immediately centrifuged. For ghrelin, but not leptin, plasma samples were acidified with $10 \%$ volume of $1 \mathrm{M} \mathrm{HCl}$ and stored at $-80{ }^{\circ} \mathrm{C}$ until assay. Acyl-ghrelin concentrations were measured in $25 \mu \mathrm{l}$ plasma with an active ghrelin ELISA kit (Mitsubishi Kagaku Iatron, Tokyo, Japan), and leptin concentrations were measured in $30 \mu \mathrm{l}$ plasma with a rat leptin ELISA kit (Yanaihara Institute Inc., Shizuoka, Japan). The assay ranges of the kits were $2 \cdot 73-175 \mathrm{fmol} / \mathrm{ml}$ ghrelin
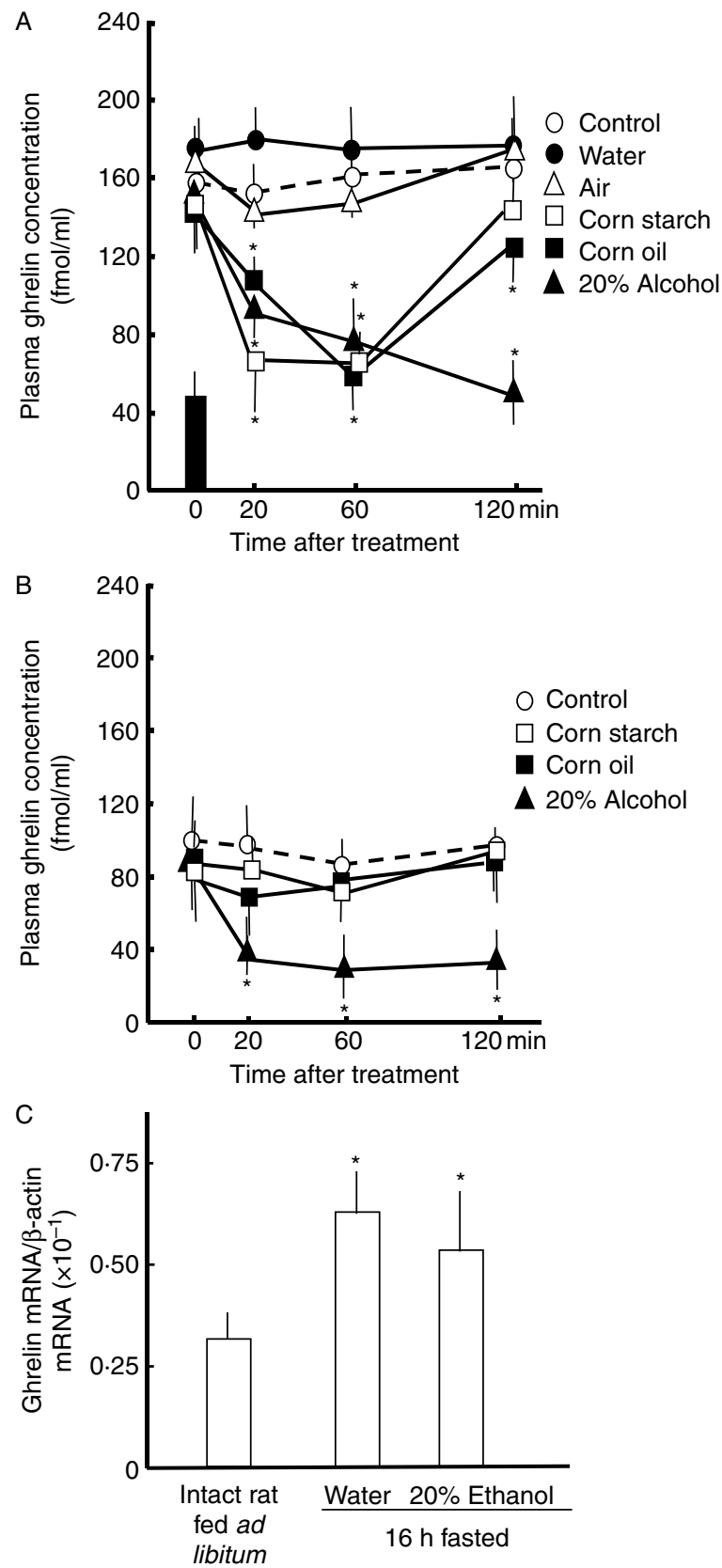

Figure 1 Effects of gastric infusion of $6 \mathrm{ml}$ air or $3 \mathrm{ml}$ water, $30 \%$ corn starch, corn oil, or $20 \%$ ethanol on plasma ghrelin levels in (A) intact and (B) vagotomized rats. Materials were infused directly into the stomach of 16-h-starved rats through an implanted gastric cannula at $0900 \mathrm{~h}$. Samples were collected at 0, 20, 60, and 120 min after infusion. The black bar in (A) represents the plasma ghrelin levels at $0900 \mathrm{~h}$ in intact rats $(n=7)$ fed ad libitum. Symbols and bars represent means, vertical lines represent S.E.M. $(n=10)$, and asterisks indicate significant differences $(P<0.05$ versus control). (C) Effect of a 16-h fast, followed by infusion of water or $20 \%$ ethanol, on levels of ghrelin mRNA in the stomach. Bars represent means, vertical lines represent S.E.M. $(n=8)$, and asterisks indicate significant differences $(P<0 \cdot 05$ versus rats fed ad libitum). 
and 312.5-20 $000 \mathrm{pg} / \mathrm{ml} \mathrm{leptin.} \mathrm{The} \mathrm{intra-} \mathrm{and} \mathrm{inter-assay}$ coefficients of variation of the ELISA were $5 \cdot 5$ and $3 \cdot 2 \%$ respectively for ghrelin, and 6.3 and $4.8 \%$ for leptin. Plasma glucose concentrations were measured with a DRI-CHEM 3500 analyzer (Fujifilm, Tokyo, Japan).

\section{Data analysis}

Control and treated groups were compared by ANOVA with Fisher's post hoc test. Differences at $P<0 \cdot 05$ were accepted as statistically significant.

\section{Results}

In 16-h-starved rats, basal plasma ghrelin levels were increased about four times in comparison with those in free-feeding rats. The direct infusion of $6 \mathrm{ml}$ air or $3 \mathrm{ml}$ water into the stomach had no effect on levels. On the other hand, $3 \mathrm{ml}$ of $30 \%$ corn starch, corn oil, or $20 \%$ ethanol significantly decreased plasma ghrelin levels (Fig. 1A). At $20 \mathrm{~min}$ after infusion, corn starch gave the greatest decrease. Levels that were decreased by corn starch and corn oil, but not by ethanol, tended to recover by $60 \mathrm{~min}$ after treatment.

Fasting for $16 \mathrm{~h}$ increased the baseline ghrelin level in vagotomized rats as well as in intact rats, but the increase in vagotomized rats was significantly smaller than that in intact rats. The increased baseline ghrelin level at $16 \mathrm{~h}$ of fasting in vagotomized rats was approximately the same level as the nadir observed after the administration of corn starch or corn oil in intact rats, as shown in Fig. 1A and B. Differently from intact rats, however, infusion of $30 \%$ corn starch or corn oil did not cause a significant decrease in the plasma level of ghrelin in vagotomized rats. On the other hand, the administration of $20 \%$ ethanol decreased the level of ghrelin to about $40 \mathrm{fmol} / \mathrm{ml}$, which was almost the same as the basal level in rats fed ad libitum (Fig. 1B).

Although the expression of ghrelin mRNA was increased by a $16-\mathrm{h}$ fast, the administration of $20 \%$ ethanol did not change ghrelin mRNA expression in the stomach at $2 \mathrm{~h}$ after treatment, in comparison with ghrelin mRNA expression in rats administered water (Fig. 1C).

Infusion of ethanol three times a day for 14 and 21 days significantly increased plasma ghrelin levels (Fig. 2B). In water-treated rats, the fundus of the stomach had an intact mucosa, lamina propria mucosae, muscularis mucosae, and gastric gland (Fig. 2C). In ethanol-treated rats, by 21 days the stomach had been injured: the normal mucosa, propria mucosae, and muscularis mucosae had almost disappeared, and widespread propria mucosae including gastric gland cells were observed. Ghrelin-positive cells were distributed in the basal part of the gastric gland in saline-treated rats, but were globally distributed with increased numbers of positive cells in ethanol-treated rats (Fig. 2C).
Exposure to low temperature $\left(13 \pm 1^{\circ} \mathrm{C}\right)$ did not change plasma ghrelin levels, but it increased leptin levels at $120 \mathrm{~min}$. On the other hand, restriction stress decreased plasma ghrelin levels and increased leptin levels time dependently (Fig. 3A and B).
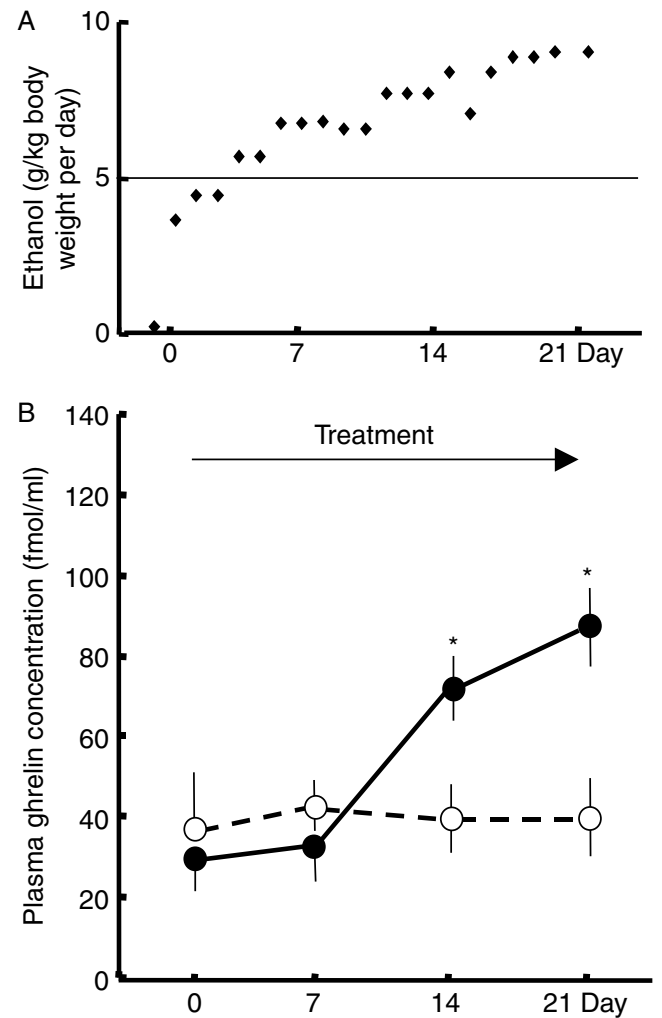

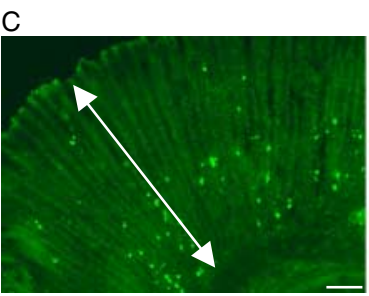

Control

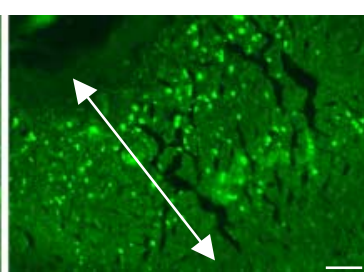

Alcohol (21 days)
Figure 2 (A) The schedule of ethanol administration. The dose of ethanol was gradually increased stepwise during 3 weeks. Although ethanol was infused into the stomach three times a day (at 0730, 1300 , and $1830 \mathrm{~h}$ ), the dose was represented by the total ethanol weight $(\mathrm{g}) / \mathrm{kg}$ bodyweight/day. (B and C) Effects of chronic treatment with ethanol on (B) plasma ghrelin levels and (C) stomach integrity. Ethanol (filled circles) and water (clear circles) were infused directly into the stomach through an implanted gastric cannula three times a day for 3 weeks. Blood samples were collected 7, 14, and 21 days after initiation of treatment. Symbols represent means, vertical lines represent S.E.M. $(n=8)$, and asterisks indicate significant differences $(P<0.05$ versus water treatment). Image in $(C)$ shows immunofluorescence staining for acyl-ghrelin in stomach section. Bar scales are $100 \mu \mathrm{m}$. The white arrow with same scale shows normal mucosa (control) and injured mucosa (ethanol treatment). Full colour version of this figure available via http://dx.doi.org/10.1677/ JOE-10-0062. 

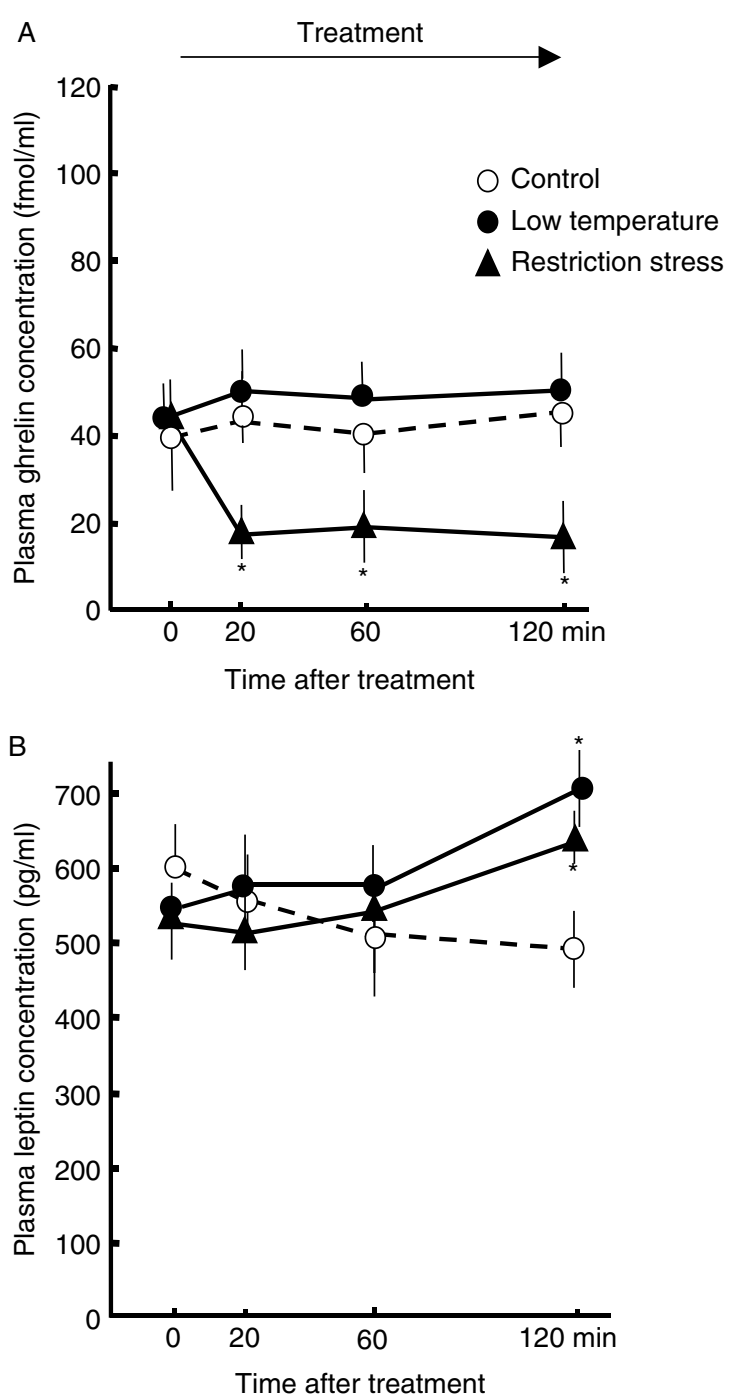

Figure 3 Effects of environmental temperature and restriction stress on (A) plasma ghrelin and (B) leptin levels. Intact rats fed ad libitum were transferred from their usual room $\left(23 \pm 1^{\circ} \mathrm{C}\right)$ to a cold room $\left(13 \pm 1{ }^{\circ} \mathrm{C}\right)$ at $0900 \mathrm{~h}$. To separate the effects of stress from the effects of temperature, some control rats were stressed by insertion into plastic tubes. Plasma samples were collected at 0, 20,60, and $120 \mathrm{~min}$. Symbols represent means, vertical lines represent S.E.M. $(n=10)$, and asterisks indicate significant differences $(P<0.05$ versus control).

A single injection of $20 \%$ glucose increased and insulin decreased blood glucose levels in free-feeding rats (Fig. 4A). Each injection significantly decreased plasma ghrelin levels 20 and 60 min after treatment, and levels returned to normal at $120 \mathrm{~min}$ (Fig. 4B). On the other hand, insulin increased plasma leptin levels at $120 \mathrm{~min}$, but glucose had no significant effect (Fig. 4C). In saline-treated rats, basal plasma leptin levels decreased $120 \mathrm{~min}$ after treatment, which might be a diurnal change (Haynes et al. 1997, Trayhurn et al. 1999).

\section{Discussion}

Basal plasma ghrelin levels and stomach ghrelin mRNA levels were increased after 16-h overnight starvation, supporting the view that ghrelin secretion is promoted by hunger. Under hunger, direct infusion of a carbohydrate or fat into the stomach significantly decreased the high plasma ghrelin levels, suggesting that they alleviated hunger. These observations agree with previous observations in rat and human (Beck et al. 2002, Greenman et al. 2004, Bowen et al. 2006, Foster-Schubert et al. 2008). As the half-life of plasma ghrelin is about $10 \mathrm{~min}$ (Hosoda et al. 2000, Kojima \& Kangawa 2005), the fact that the plasma ghrelin levels decreased to half levels at $20 \mathrm{~min}$ after the administration of $30 \%$ corn starch, corn oil, and $20 \%$ ethanol suggests that de novo secretion of ghrelin in the stomach was halted after those administration. In contrast, the infusion of air or water did not change the plasma ghrelin level. Although water, 30\% corn starch, and corn oil pass from the stomach to the duodenum at different rates, making it difficult to compare their effects on the stomach, these results together with previous reports suggest that mechanical stimulation of the stomach is not effective at provoking ghrelin secretion under hunger (Kojima \& Kangawa 2005). In addition, both the acute $(<20 \mathrm{~min})$ and long-term suppression ( $>1 \mathrm{~h}$ ) of plasma ghrelin levels by $30 \%$ corn starch, corn oil, and $20 \%$ ethanol suggest that suppression depends on both neuronal (acute) and humoral (long term) action. Although the amount of calories administered differed among 30\% corn starch, corn oil, and $20 \%$ ethanol, the strength of suppression was almost the same at 20 and $60 \mathrm{~min}$ after these treatments. Therefore, the suppression may not have been due to nutritional calories, but may be due to chemical stimulation by the carbohydrate, protein, and ethanol. The most long-term suppression was observed after the administration of $20 \%$ ethanol. As the expression of ghrelin mRNA in the stomach was not changed by $20 \%$ ethanol at $2 \mathrm{~h}$ after administration, this long-term suppression did not appear to be due to a decrease in ghrelin synthesis.

Vagotomy partially inhibited the baseline increase caused by $16 \mathrm{~h}$ of fasting, and completely inhibited the decrease of ghrelin secretion induced by administration of corn starch or corn oil. The increased baseline ghrelin level at $16 \mathrm{~h}$ of fasting in vagotomized rats was approximately the same level as the nadir observed after the administration of corn starch or corn oil in intact rats. These results suggest that the central nervous system (CNS) in vagotomized rats might not adequately perceive the metabolic state of starvation, suggesting that the underlying pathophysiology may involve impairment of afferent, rather than of efferent, innervations of the stomach. We previously reported that electrical stimulation of the vagus nerve increased the plasma ghrelin level in rat (Murakami et al. 2002). On the other hand, vagus stimulation exaggerates the inhibitory ghrelin response to oral fat in humans, probably through activation of the vagal afferent impulse (Heath et al. 2004). Although the reason for the discrepancy between the 

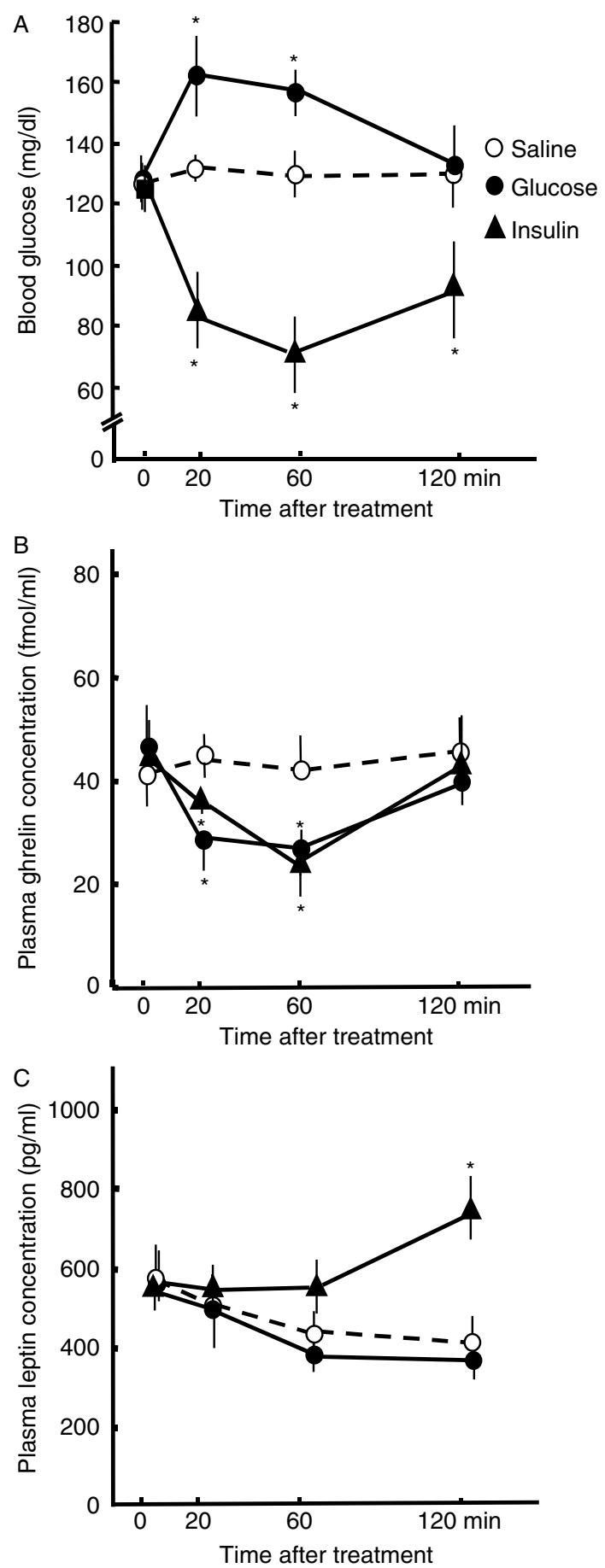

Figure 4 Effect of glucose and insulin in intact rats fed ad libitum on (A) plasma glucose, (B) ghrelin, and (C) leptin levels. Either $200 \mu \mathrm{l}$ of insulin or $500 \mu \mathrm{l}$ of $20 \%$ glucose solution was injected s.c. at $0900 \mathrm{~h}$. Blood was collected at 0, 20, 60, and $120 \mathrm{~min}$ after treatment. Control rats were treated with saline. Symbols represent means, vertical lines represent S.E.M. $(n=10)$, and asterisks indicate significant differences $(P<0 \cdot 05$ versus control). stimulatory and inhibitory effects evoked by vagal simulation is unknown, these results suggest that the vagus nerve may play an important role in ghrelin secretion by transmitting nutrient information to the CNS as an afferent impulse, or CNS information to the stomach as an efferent impulse.

Acute infusion of ethanol into the stomach strongly suppressed ghrelin secretion. This remains to be understood because of the complexity of peripheral or central action of alcohol. However, vagotomy did not prevent this alcoholinduced suppression of ghrelin secretion, suggesting that alcohol acts directly. In human, ghrelin declined significantly within $15 \mathrm{~min}$ after alcohol intake, fell to a minimum of $66 \%$ of baseline at $75 \mathrm{~min}$, and remained at that level until the last sample at $120 \mathrm{~min}$ (Zimmerman et al. 2007). Our results show that chronic ethanol treatment caused major injury in the stomach, eroding the mucosa, propria mucosae, and muscularis mucosae, and revealing widespread propria mucosae including gastric gland cells. Interestingly, and in contrast, ghrelin-positive cells were globally distributed with increased numbers in alcohol-treated rats, and plasma ghrelin levels were subsequently increased. From this observation, we speculate that ghrelin plays an important role in the restoration of stomach mucosa injured by alcohol (Konturek et al. 2004, 2009). Sibilia et al. (2003) reported that i.c.v. or i.p. injection of ghrelin at $30 \mathrm{~min}$ before oral treatment with $1 \mathrm{ml}$ of $50 \%$ alcohol reduced the incidence of alcohol-induced gastric ulcers in rats by mediating endogenous nitric oxide release and stimulating the vagus nerve. On the other hand, Konturek et al. (2004) reported that i.p. injection of ghrelin at $30 \mathrm{~min}$ before intragastric administration of $1.5 \mathrm{ml}$ of $75 \%$ ethanol decreased the incidence of acute ethanol-induced gastric lesions by mediating prostaglandins. In addition, ghrelin stimulates cell proliferation (Nakahara et al. 2006). Our results demonstrate, therefore, that an increase of ghrelin-positive cells in stomach injured by chronic ethanol treatment may be an attempt to restore the mucosa. Further study is required to examine what increases the number of ghrelin-positive cells.

Exposure to low temperature increased plasma leptin levels but had no effect on ghrelin levels. Restriction stress decreased plasma ghrelin levels and increased leptin levels. These results suggest that the changes in levels in response to temperature were not due to stress, and that low temperatureinduced increase in plasma leptin may play important roles in thermoregulation. Several observations of the relationship between plasma ghrelin and leptin levels in hibernators and environmental temperature are reported (Korhonen et al. 2008, Zhang et al. 2009). However, the responses in hibernators are responses to seasonal or long-term changes in temperature, and are not acute responses as presented here. Thermogenesis in brown adipose tissue (BAT) depends on activation and increased expression of $\beta 3$-adrenergic receptors and the consequent up-regulation of uncoupling protein 1 (UCP1; Cannon \& Nedergaard 2004). This activation is partially regulated by the sympathetic nerves, and i.c.v. administration of ghrelin and leptin respectively 
suppresses and stimulates sympathetic efferent signaling to BAT (Friedman \& Halaas 1998, Ahima \& Flier 2000, Yasuda et al. 2003, Mano-Otagiri et al. 2009). In addition, leptin and ghrelin respectively increased and decreased the expression of UCP1 mRNA in BAT (Pelleymounter et al. 1995, Scarpace \& Matheny 1998, Theander-Carrillo et al. 2006, Mano-Otagiri et al. 2010). Therefore, leptin, but not ghrelin, release under low temperature may promote thermogenesis and increase body temperature (Asakuma et al. 2003).

I.c.v. injection of ghrelin increased core temperature in rats (Jászberényi et al. 2006). Although we do not know the reason for this discrepancy between the effects of ghrelin on body temperature, the effects of central and peripheral ghrelin on thermoregulation may be different, since peripheral ghrelin acts on the CNS via the vagus nerve (Date et al. 2002a). Further study is required to elucidate how ghrelin controls body temperature.

Leptin and ghrelin are involved in hypothalamo-pituitaryadrenal (HPA) responses to stressful stimuli (Spinedi \& Gaillard 1998, Kristenssson et al. 2006, Patterson-Buckendahl et al. 2007, Ochi et al. 2008). Here, restriction stress decreased plasma ghrelin levels and increased leptin levels. Although the mechanism of these reciprocal responses to stress is not clear, endogenous ghrelin and leptin may play important roles in stress responses. Plasma ghrelin levels decreased significantly from 20 min onward during stress treatments. On the other hand, acute psychological stress raises them (Kristenssson et al. 2006). In addition, Zimmermann et al. (2007) have reported that psychological stress in humans does not affect ghrelin secretion. Although we do not know the reason for this discrepancy, the ghrelin response to stress may be different depending on exogenous (such as mechanical or environmental) and endogenous (such as psychological) stresses. Plasma leptin levels showed a significant increase at $120 \mathrm{~min}$, but not at 20 or $60 \mathrm{~min}$, suggesting that leptin responds more slowly to stress than ghrelin. An i.c.v. injection of leptin attenuated the increases in hypothalamic noradrenaline release and plasma ACTH concentrations after electrical foot-shock stress (Kawakami et al. 2008). On the other hand, leptin activated the HPA axis (van Dijk et al. 1997). It is not likely that the slow response of leptin shown here activates the HPA axis.

It has been well documented that insulin interacts with ghrelin and leptin (Adeghate \& Ponery 2002, Date et al. 2002b, Lee et al. 2002, Saad et al. 2002, Kapica et al. 2008). The pancreatic $\beta$-cells have receptors for both ghrelin and leptin (Kieffer et al. 1996, Date et al. 2002b). Exogenous administration of leptin decreases insulin secretion (Fehmann et al. 1997, Kulkarni et al. 1997, Poitout et al. 1998), but ghrelin stimulates or inhibits insulin secretion depending on dose or experimental conditions (Date et al. 2002b). The exogenous administration of insulin inhibited ghrelin secretion and stimulated leptin secretion (Nakagawa et al. 2002, Saad et al. 2002, Seufert 2004). Our results clearly support those observations. However, the time course of the responses to insulin and glucose differed between ghrelin and leptin. Plasma ghrelin decreased significantly by $20 \mathrm{~min}$ after insulin treatment and returned to basal levels by $120 \mathrm{~min}$. Although the plasma glucose levels showed opposite responses to insulin and $20 \%$ glucose solution, plasma ghrelin levels decreased in response to both. These results suggest that insulin and glucose independently decreased ghrelin secretion. However, the possibility that the ghrelin suppression after glucose was brought about by glucose-induced insulin secretion remains.

Plasma leptin levels showed a significant increase by 120 min after treatment with insulin, but no significant change after glucose. Hypoglycemia induced by a glucose clamp technique increased plasma leptin levels in women (Ludwig et al. 2007). Therefore, the significant increase of leptin may be due to either the direct action of insulin or the insulin-induced hypoglycemia.

In conclusion, our results demonstrate that not only exogenous stimuli, such as temperature and stress, but also endogenous factors, such as nutrition, hyperglycemia, hypoglycemia, and insulin, affect the plasma levels of ghrelin and leptin in almost reciprocal fashion. This acute response may maintain homeostasis for many physiological functions.

\section{Declaration of interest}

The authors declare that there is no conflict of interest that could be perceived as prejudicing the impartiality of the research reported.

\section{Funding}

This study was supported in part by grants-in-aid from the Ministry of Education, Science, Sports and Culture of Japan and by the Program for Promotion of Basic Research Activities for Innovative Bioscience (PROBRAIN).

\section{References}

Adeghate E \& Ponery AS 2002 Ghrelin stimulates insulin secretion from the pancreas of normal and diabetic rats. Journal of Neuroendocrinology 14 555-560. (doi:10.1046/j.1365-2826.2002.00811.x)

Ahima RS \& Flier JS 2000 Leptin. Annual Review of Physiology 62 413-437. (doi:10.1146/annurev.physiol.62.1.413)

Asakuma S, Morishita H, Sugino T, Kurose Y, Kobayashi S \& Terashima Y 2003 Circulating leptin response to feeding and exogenous infusion of insulin in sheep exposed to thermoneutral and cold environments. Comparative Biochemistry and Physiology, Part A 134 329-335. (doi:10.1016/ S1095-6433(02)00269-6)

Beck B, Musse N \& Stricker-Krongrad A 2002 Ghrelin, macronutrient intake and dietary preferences in Long-Evans rats. Biochemical and Biophysical Research Communications 292 1031-1035. (doi:10.1006/bbrc.2002.6737)

Bowen J, Noakes M, Trenerry C \& Clifton PM 2006 Energy intake, ghrelin, and cholecystokinin after different carbohydrate and protein preloads in overweight men. Journal of Clinical Endocrinology and Metabolism $\mathbf{9 1}$ 1477-1483. (doi:10.1210/jc.2005-1856)

Cannon B \& Nedergaard J 2004 Brown adipose tissue: function and physiological significance. Physiological Reviews 84 277-359. (doi:10.1152/ physrev.00015.2003) 
Date Y, Kojima M, Hosoda H, Sawaguchi A, Mondal MS, Suganuma T, Matsukura S, Kangawa K \& Nakazato M 2000 Ghrelin, a novel growth hormone-releasing acylated peptide, is synthesized in a distinct endocrine cell type in the gastrointestinal tracts of rats and humans. Endocrinology 141 4255-4261. (doi:10.1210/en.141.11.4255)

Date Y, Murakami N, Nijima A, Matsukura S, Matsuo H, Kangawa K \& Nakazato M 2002a The role of gastric vagal afferent in feeding and growth hormone secretion effects of ghrelin. Gastroenterology 123 1120-1128. (doi:10.1053/gast.2002.35954)

Date Y, Nakazato M, Hashiguchi S, Dezaki K, Mondal MS, Hosoda H, Kojima M, Kangawa K, Arima T, Matsuo H et al. $2002 b$ Ghrelin is present in pancreatic $\alpha$-cells of humans and rats and stimulates insulin secretion. Diabetes 51 124-129. (doi:10.2337/diabetes.51.1.124)

Fehmann HC, Berghöfer P, Brandhorst D, Brandhorst H, Hering B, Bretzel RG \& Göke B 1997 Leptin inhibition of insulin secretion from isolated human islets. Acta Diabetologica 34 249-252. (doi:10.1007/ s005920050083)

Foster-Schubert KE, Overduin J, Prudom CE, Liu J, Callahan HS, Gaylinn BD, Thorner MO \& Cummings DE 2008 Acyl and total ghrelin are suppressed strongly by ingested proteins, weakly by lipids, and biophysically by carbohydrates. Journal of Clinical Endocrinology and Metabolism $\mathbf{9 3}$ 1971-1979. (doi:10.1210/jc.2007-2289)

Friedman JM \& Halaas JL 1998 Leptin and the regulation of body weight in mammals. Nature 395 763-770. (doi:10.1038/27376)

Greenman Y, Golani N, Gilad S, Yaron M, Limor R \& Stern N 2004 Ghrelin secretion is modulated in a nutrient- and gender-specific manner. Clinical Endocrinology 60 382-388. (doi:10.1111/j.1365-2265.2004.01993.x)

Gualillo O, Caminos J, Blanco M, Garcia-Caballero T, Kojima M, Kangawa K, Dieguez C \& Casanueva F 2001 Ghrelin, a novel placental-derived hormone. Endocrinology 142 788-794. (doi:10.1210/en.142.2.788)

Hattori N, Saito T, Yagyu T, Jiang BH, Kitagawa K \& Inagaki C 2001 GH, $\mathrm{GH}$ receptor, $\mathrm{GH}$ secretagogue receptor, and ghrelin expression in human $\mathrm{T}$ cells, B cells, and neutrophils. Journal of Clinical Endocrinology and Metabolism 86 4284-4291. (doi:10.1210/jc.86.9.4284)

Haynes WG, Sivitz WI, Morgan DA, Walsh SA \& Mark AL 1997 Sympathetic and cardiorenal actions of leptin. Hypertension 30 619-623.

Heath RB, Jones R, Frayn KN \& Robertson MD 2004 Vagal stimulation exaggerates the inhibitory ghrelin response to oral fat in humans. Journal of Endocrinology 180 273-281. (doi:10.1677/joe.0.1800273)

Hosoda H, Kojima M, Matsuo H \& Kangawa K 2000 Ghrelin and des-acyl ghrelin: two major forms of rat ghrelin peptide in gastrointestinal tissue. Biochemical and Biophysical Research Communications 279 909-913. (doi:10. 1006/bbrc.2000.4039)

Jászberényi M, Bujdosó E, Bagosi Z \& Telegdy G 2006 Mediation of the behavioral, endocrine and thermoregulatory actions of ghrelin. Hormones and Behavior 50 266-273. (doi:10.1016/j.yhbeh.2006.03.010)

Kapica M, Puzio I, Kato I, Kuwahara A \& Zabielski R 2008 Role of feedregulating peptides on pancreatic exocrine secretion. Journal of Physiology and Pharmacology 59 145-159.

Katayama T, Shimamoto S, Oda H, Nakahara K, Kangawa K \& Murakami N 2007 Glucagon receptor expression and glucagon stimulation of ghrelin secretion in rat stomach. Biochemical and Biophysical Research Communications 357 865-870. (doi:10.1016/j.bbrc.2007.04.001)

Kawakami A, Okada N, Rokkaku K, Honda K, Ishibashi S \& Onaka T 2008 Leptin inhibits and ghrelin augments hypothalamic noradrenaline release after stress. Stress 11 363-369. (doi:10.1080/10253890701820257)

Kieffer TJ, Heller RS \& Habener JF 1996 Leptin receptors expressed on pancreatic $\beta$-cells. Biochemical and Biophysical Research Communications 224 522-527. (doi:10.1006/bbrc.1996.1059)

Kojima M \& Kangawa K 2005 Ghrelin: structure and function. Physiological Reviews 85 495-522. (doi:10.1152/physrev.00012.2004)

Kojima M, Hosoda H, Date Y, Nakazato M, Matsuo H \& Kangawa K 1999 Ghrelin is a growth-hormone-releasing acylated peptide from stomach. Nature 402 656-660. (doi:10.1038/45230)

Konturek PC, Brzozowski T, Pajdo R, Nikiforuk A, Kwiecien S, Harsch I, Drozdowicz D, Hahn EG \& Konturek SJ 2004 Ghrelin - a new gastroprotective factor in gastric mucosa. Journal of Physiology and Pharmacology 55 325-336.
Konturek PC, Brzozowski T, Engel M, Burnat G, Gaca P, Kwiecien S, Pajdo R \& Konturek SJ 2009 Ghrelin ameliorates colonic inflammation. Role of nitric oxide and sensory nerves. Journal of Physiology and Pharmacology 60 41-47.

Korbonits M, Bustin SA, Kojima M, Jordan S, Adams EF, Lowe DG, Kangawa K \& Grossman AB 2001 The expression of the growth hormone secretagogue receptor ligand ghrelin in normal and abnormal human pituitary and other neuroendocrine tumors. Journal of Clinical Endocrinology and Metabolism 86 881-887. (doi:10.1210/jc.86.2.881)

Korhonen T, Mustonen AM, Nieminen P \& Saarela S 2008 Effects of cold exposure, exogenous melatonin and short-day treatment on the weightregulation and body temperature of the Siberian hamster. Regulatory Peptides 149 60-66. (doi:10.1016/j.regpep.2007.09.033)

Kristenssson E, Sundqvist M, Astin M, Kjerling M, Mattsson H, Dornonville de la Cour C, Håkanson R \& Lindström E 2006 Acute psychological stress raises plasma ghrelin in the rat. Regulatory Peptides 134 114-117. (doi:10.1016/j.regpep.2006.02.003)

Kulkarni RN, Wang ZL, Wang RM, Hurley JD, Smith DM, Ghatei MA, Withers DJ, Gardiner JV, Bailey CJ \& Bloom SR 1997 Leptin rapidly suppresses insulin release from insulinoma cells, rat and human islets and, in vivo, in mice. Journal of Clinical Investigation 100 2729-2736. (doi:10. 1172/JCI119818)

Lee HM, Wang G, Englander EW, Kojima M \& Greeley GH Jr 2002 Ghrelin, a new gastrointestinal endocrine peptide that stimulates insulin secretion: enteric distribution, ontogeny, influence of endocrine, and dietary manipulations. Endocrinology 143 185-190. (doi:10.1210/en.143.1.185)

Ludwig AK, Weiss JM, Tauchert S, Dietze T, Rudolf S, Diedrich K, Peters A \& Oltmanns KM 2007 Influence of hypo- and hyperglycaemia on plasma leptin concentrations in healthy women and in women with polycystic ovary syndrome. Human Reproduction 22 1555-1561. (doi:10.1093/humrep/dem041)

Mano-Otagiri A, Ohata H, Iwasaki-Sekino A, Nemoto T \& Shibasaki T 2009 Ghrelin suppresses noradrenaline release in the brown adipose tissue of rats. Journal of Endocrinology 201 341-349. (doi:10.1677/JOE-08-0374)

Mano-Otagiri A, Iwasaki-Sekino A, Nemoto T, Ohata H, Shuto Y, Nakabayashi H, Sugihara H, Oikawa S \& Shibasaki T 2010 Genetic suppression of ghrelin receptors activates brown adipocyte function and decreases fat storage in rats. Regulatory Peptides 160 81-90. (doi:10.1016/ j.regpep.2009.11.010)

Masuzaki H, Ogawa Y, Sagawa N, Hosoda K, Matsumoto T, Mise H, Nishimura H, Yoshimasa Y, Tanaka I, Mori T et al. 1997 Nonadipose tissue production of leptin: leptin as a novel placenta-derived hormone in humans. Nature Medicine 3 1029-1033. (doi:10.1038/nm0997-1029)

Mori K, Yoshimoto A, Takaya K, Hosoda K, Ariyasu H, Yahata K, Mukoyama M, Sugawara A, Hosoda H, Kojima M et al. 2000 Kidney produces a novel acylated peptide, ghrelin. FEBS Letters 486 213-216. (doi:10.1016/S00145793(00)02308-5)

Murakami N, Hayashida T, Kuroiwa T, Nakahara K, Ida T, Mondal MS, Nakazato M, Kojima M \& Kangawa K 2002 Role for central ghrelin in food intake and secretion profile of stomach ghrelin in rats. Journal of Endocrinology 174 283-288. (doi:10.1677/joe.0.1740283)

Nakagawa E, Nagaya N, Okumura H, Enomoto M, Oya H, Ono F, Hosoda H, Kojima M \& Kangawa K 2002 Hyperglycaemia suppresses the secretion of ghrelin, a novel growth-hormone-releasing peptide: responses to the intravenous and oral administration of glucose. Clinical Science 103 325-328.

Nakahara K, Nakagawa M, Baba Y, Sato M, Toshinai K, Date Y, Nakazato M, Kojima M, Miyazato M, Kaiya H et al. 2006 Maternal ghrelin plays an important role in rat fetal development during pregnancy. Endocrinology 147 1333-1342. (doi:10.1210/en.2005-0708)

Nakazato M, Murakami N, Date Y, Kojima M, Matsuo H, Kangawa K \& Matsukura S 2001 A role for ghrelin in the central regulation of feeding. Nature 409 194-198. (doi:10.1038/35051587)

Nass R, Farhy LS, Liu J, Prudom CE, Johnson ML, Veldhuis P, Pezzoli SS, Oliveri MC, Gaylinn BD, Geysen HM et al. 2008 Evidence for acyl-ghrelin modulation of growth hormone release in the fed state. Journal of Clinical Endocrinology and Metabolism 93 1988-1994. (doi:10.1210/jc.2007-2234)

Nishimura G, Nakahara K, Misaw N, Muranaka M, Uchida K, Kuroda H \& Murakami N 2001 Immunization against intestinal bacterial endotoxin prevents alcoholic fatty liver in rats. Journal of Veterinary Medical Science $\mathbf{6 3}$ 275-280. (doi:10.1292/jvms.63.275) 
Ochi M, Tominaga K, Tanaka F, Tanigawa T, Shiba M, Watanabe T, Fujiwara Y, Oshitani N, Higuchi K \& Arakawa T 2008 Effect of chronic stress on gastric emptying and plasma ghrelin levels in rats. Life Sciences 82 862-868. (doi:10.1016/j.lfs.2008.01.020)

Olszanecka-Glinianowicz M, Zahorska-Markiewicz B, Zurakowski A \& Glinianowicz M 2005 The role of tumor necrosis factor (TNF- $\alpha$ ) in control of metabolism. Wiadomości Lekarskie 58 670-674.

Patterson-Buckendahl P, Pohorecky LA \& Kvetnansky R 2007 Differing effects of acute and chronic stressors on plasma osteocalcin and leptin in rats. Stress 10 163-172. (doi:10.1080/10253890701317601)

Pelleymounter MA, Cullen MJ, Baker MB, Hecht R, Winters D, Boone T \& Collins F 1995 Effects of the obese gene product on body weight regulation in ob/ob mice. Science 269 540-543. (doi:10.1126/science. 7624776)

Poitout V, Rouault C, Guerre-Millo M, Briaud I \& Reach G 1998 Inhibition of insulin secretion by leptin in normal rodent islets of Langerhans. Endocrinology 139 822-826. (doi:10.1210/en.139.3.822)

Saad MF, Bernaba B, Hwu CM, Jinagouda S, Fahmi S, Kogosov E \& Boyadjian R 2002 Insulin regulates plasma ghrelin concentration. Clinics in Endocrinology and Metabolism 87 3997-4000. (doi:10.1210/jc.87.8.3997)

Sato M, Nakahara K, Miyazato M, Kangawa K \& Murakami N 2007 Regulation of $\mathrm{GH}$ secretagogue receptor gene expression in the rat nodose ganglion. Journal of Endocrinology 194 41-46. (doi:10.1677/ JOE-06-0078)

Scarpace PJ \& Matheny M 1998 Leptin induction of UCP1 gene expression is dependent on sympathetic innervation. American Journal of Physiology Endocrinology and Metabolism 275 E259-E264.

Seufert J 2004 Leptin effects on pancreatic $\beta$-cell gene expression and function. Diabetes 53 S152-S158. (doi:10.2337/diabetes.53.2007.S152)

Shimada M, Date Y, Mondal MS, Toshinai K, Shimbara T, Fukunaga K, Murakami N, Miyazato M, Kangawa K, Yoshimatsu H et al. 2003 Somatostatin suppresses ghrelin secretion from the rat stomach. Biochemical and Biophysical Research Communications 302 520-525. (doi:10.1016/S0006291X(03)00178-5)

Sibilia V, Rindi G, Pagani F, Rapetti D, Locatelli V, Torsello A, Campanini N, Deghenghi R \& Netti C 2003 Ghrelin protects against ethanol-induced gastric ulcers in rats: studies on the mechanisms of action. Endocrinology 144 353-359. (doi:10.1210/en.2002-220756)

Spinedi E \& Gaillard RC 1998 A regulatory loop between the hypothalamopituitary- adrenal (HPA) axis and circulating leptin: a physiological role of ACTH. Endocrinology 139 4016-4020. (doi:10.1210/en.139.9.4016)

Szkudelski T 2007 Intracellular mediators in regulation of leptin secretion from adipocytes. Physiological Research 56 503-512.
Theander-Carrillo C, Wiedmer P, Cettour-Rose P, Nogueiras R, Perez-Tilve D, Pfluger P, Castaneda TR, Muzzin P, Schürmann A, Szanto I et al. 2006 Ghrelin action in the brain controls adipocyte metabolism. Journal of Clinical Investigation 116 1983-1993. (doi:10.1172/JCI25811)

Toshinai K, Mondal MS, Nakazato M, Date Y, Murakami N, Kojima M, Kangawa K \& Matsukura S 2001 Upregulation of ghrelin expression in the stomach upon fasting, insulin-induced hypoglycemia, and leptin administration. Biochemical and Biophysical Research Communications 281 1220-1225. (doi:10.1006/bbrc.2001.4518)

Trayhurn P, Hoggard N, Mercer JG \& Rayner DV 1999 Leptin: fundamental aspects. International Journal of Obesity and Related Metabolic Disorders 23 S22-S28. (doi:10.1038/sj.ijo.0800791)

van Dijk G, Donahey JC, Thiele TE, Scheurink AJ, Steffens AB, Wilkinson CW, Tenenbaum R, Campfield LA, Burn P, Seeley RJ et al. 1997 Central leptin stimulates corticosterone secretion at the onset of the dark phase. Diabetes 46 1911-1914.

Yasuda T, Masaki T, Kakuma T \& Yoshimatsu H 2003 Centrally administered ghrelin suppresses sympathetic nerve activity in brown adipose tissue of rats. Neuroscience Letters 349 75-78. (doi:10.1016/S0304-3940(03)00789-4)

Zhang Y, Proenca R, Maffei M, Barone M, Leopold L \& Friedman JM 1994 Positional cloning of the mouse obese gene and its human homologue. Nature 372 425-432. (doi:10.1038/372425a0)

Zhang M, Yuan F, Liu H, Chen H, Qiu X \& Fang W 2008 Inhibition of proliferation and apoptosis of vascular smooth muscle cells by ghrelin. Acta Biochimica et Biophysica Sinica 40 769-776. (doi:10.1093/ abbs/40.9.769)

Zhang XY, Jing BB \& Wang DH 2009 Cold exposure does not decrease serum leptin concentration, but increases energy intake and thermogenic capacity in pregnant Brandt's voles (Lasiopodomys brandtii). Zoology 112 206-216. (doi:10.1016/j.zool.2008.09.003)

Zimmermann US, Buchmann A, Steffin B, Dieterle C \& Uhr M 2007 Alcohol administration acutely inhibits ghrelin secretion in an experiment involving psychosocial stress. Addiction Biology 12 17-21. (doi:10.1111/ j.1369-1600.2006.00026.x)

Received in final form 10 June 2010

Accepted 14 July 2010

Made available online as an Accepted Preprint

14 July 2010 